\title{
Representing Water: visual anthropology and divergent trajectories in human environmental relations
}

\section{Veronica Strang}

\section{(2) OpenEdition Journals}

Electronic version

URL: http://journals.openedition.org/aa/1175

DOI: 10.4000/aa. 1175

ISSN: 2357-738X

\section{Publisher}

Programa de Pós-Graduação em Antropologia Social (UnB)

\section{Printed version}

Date of publication: 1 December 2011

Number of pages: 213-242

ISSN: 0102-4302

\section{Electronic reference}

Veronica Strang, "Representing Water: visual anthropology and divergent trajectories in human environmental relations", Anuário Antropológico [Online], v.36 n. 1 | 2011, Online since 24 November 2015, connection on 28 April 2021. URL: http://journals.openedition.org/aa/1175; DOI: https://doi.org/ 10.4000/aa. 1175

\section{(c) $($ ) $(3)$}

Anuário Antropológico is licensed under a Creative Commons Atribuição-Uso Não-Comercial-Proibição de realização de Obras Derivadas 4.0 International. 


\title{
Representing Water: visual anthropology and divergent trajectories in human environmental relations
}

\author{
Veronica Strang \\ University of Auckland
}

Because of the centrality of water in all aspects of human life, visual, textual and other representations of water are useful in articulating the cosmological beliefs and values - and the concomitant practices - that compose societies' broader relationships with the material world. Anthropologists and scholars in related disciplines have therefore made comparative analyses of such representations to elucidate human-environmental relationships, cultural engagements with water and the cosmological principles that these express (eg. Davis, 1986; Drewal, 2008; Giblett, 1996; Morphy, 1991; Strang, 2002).

Similarly, earlier images of water and water beings help to illuminate people's historic and even prehistoric relationships with water, and their cosmological frames (Chaloupka, 1993; Layton and Ucko, 1999; Oestigaard, 2005). This suggests that an analysis of water imagery has some potential not only to enable cross-cultural comparison, but also to assist efforts to understand historical changes in human-environmental relations. Although there is a wealth of research concerned with changes in technology and material practices (eg. Juuti et al. 2007) and a broad literature describing religious and social developments (eg. Boomgaard, 2007; Harrison, 1999), the articulation between these remains somewhat elusive. This research therefore entails a systematic temporal and spatial comparative analysis of water imagery, with a view to drawing out important connections between cosmological and material changes in human engagements with water and with the broader ecosystems that societies inhabit. Thus it aims to trace the trajectories of human-environmental relationships by examining water imagery and its transformations in conjunction with contextual ethnographic, historical, archaeological and ecological data. This process will help to define the factors that have led to very different trajectories of development, and which continue to influence human-environmental engagements. The major goal of the research is to highlight key transformations and turning points that have led to divergences and to the diverse beliefs, values and practices that underlie contemporary conflicts over water.

Anuário Antropológico/2010-II, 2011: 213-242 


\section{Origins}

Early images of water in many cultural and geographic contexts often focused on water beings: river gods and goddesses, dragons ${ }^{1}$ and leviathans. Emerging from origin myths centering on the creative, generative role of water, these beings possessed supernatural powers. Like the primal waters they represented, through involvement in hydrological cycles and through the generation of water and thus resources, they held a vital creative role in the ongoing production of people and environments. Classic examples include Mesopotamian figures such as Osiris; Celtic river beings; and the Australian Rainbow Serpent. Such figures inhabited animated, sentient land and water scapes, in which spiritual forces were seen as immanent aspects of the material world, to be engaged with and propitiated. They were thus integral to environmental relationships in which non-human and supernatural forces were positioned as collaborative (and sometimes more powerful) partners with human actors.

The preliminary research described here, which is part of a broader project, suggests that in many cultural contexts a key historical transition was a shift away from this focus on what may be called "nature religions" towards increasingly humanised religious cosmologies led by human or human-like figures. In Durkheimian terms, ${ }^{2}$ this indicates a fundamental change in human-environmental relationships, as perceptions of agency shifted from a location in 'natural' or supernatural forces to an assumption of human or superhuman direction. Indicative of a cosmological separation between humankind and other species, such changes form the basis for a more dualistic vision of nature and culture which, as various writers such have observed, has led to a distancing alienation in human-environmental relations (Descola and Palsson, 1996; Ingold, 2000). This, in turn, has enabled more competitive, adversarial modes of environmental engagement.

These divergent trajectories are evident in contemporary differences between those groups who have maintained notions of sentient environments with whom they interact collaboratively, and those for whom spiritual being has been abstracted from their immediate material surroundings and relocated in humanised spiritual beings. Central to this research is a question about how critical changes in water use - the introduction of irrigation and other managerial technologies - intersect with these transformations in religious and secular ideas. Earlier research hinted at some important conjunctions between such transformative events, and suggested a useful "triangle" of foci of investigation, examining the relationships between cosmological ideas, material engagements with water, and representations of water and water beings. A fuller analysis of 
these key areas will test the hypothesis that a disembedding of spiritual beliefs from local material environments is linked with more directive - and increasingly exploitative - material practices and forms of resource use. This hypothesis implies a critical shift in a perceived balance of power, from relationships between societies and sentient co-directive environments, to relationships in which spiritual agency is humanised and human agency becomes dominant.

Diverse environmental relationships, and thus conflicts over resource use and management, are common in post-colonial societies, where indigenous peoples and their traditional belief systems have been engulfed by larger settler societies whose visions of the world have taken a more environmentally directive turn. In both Australia and New Zealand, for example, indigenous groups are now engaged in struggles to uphold their own cosmological concepts and values in societies that have adopted a much more managerial and utilitarian approach to the material environment. But the roots of such conflicts lie in the past.

\section{Tracing the Past}

Using water imagery to trace changes in environmental relations, and thus to illuminate past worlds, raises a number of theoretical and methodological challenges. The methods central to visual anthropology, which are so useful in deconstructing the relationships between people and environments, rely heavily on understanding the specific ethnographic context in which images and objects (as well as performative media) are produced and used. The analytic process of deconstructing textual and other discursive forms is equally reliant upon context: like images, these are 'embedded and continually emergent phenomena' (Barber, 2012: in press). Both visual and non-visual representational processes are 'communicative acts' which are dynamically co-produced between artists, speakers, performers and their audiences (Gal, 2012: in press).

A theoretical approach recognising this dynamism is illustrated, for example, by Morphy's analysis of Aboriginal art in Australia (2010), which makes it clear that art production is not merely concerned with making 'pretty pictures', but is primarily a form of social action directed towards political goals and the protection of indigenous lifeways. Once produced, such images also have their own "life story", acquiring new meanings and purposes as they move through different spatio-temporal contexts (Appadurai, 1986). Thus, as I have noted elsewhere, traditional images of water beings, once created primarily for the internal intergenerational transmission of knowledge, now have broader uses, as educational media that promote indigenous interests in contemporary political arena (Strang, 2010). 
While maintaining an anthropological aim to contextualise representations as fully as possible, the temporal depth necessitates a more interdisciplinary methodology. It therefore also draws upon the analytic approaches of archaeology, art history, environmental history and religious history. As noted above, there are three key foci for the investigation. First, by focusing primarily on visual images of water, it adopts deconstructive methods from visual anthropology and art history to consider the form of these images and their transformations over time. Where non-visual imagery - ie. related documentary evidence - is available, the same principles are applied to ask "how does this describe water and human relationships with it; how do these descriptions alter over time; what is their particular life story?" Second, it considers the broader cosmological beliefs and values particular to that temporal and spatial context. Third, the research juxtaposes these analyses with temporally concurrent evidence relating to societies' material engagements with water. There is a wealth of archaeological and historical research on water use practices, such as the development of irrigation schemes, canals and so forth, which can assist this process (eg. Christie, 2007; Tvedt and Jacobsson, 2006).

By examining particular societal trajectories comparatively, the analysis seeks to reveal recurrent patterns of change and transformation. This comparative approach is essential to the project: there are some limitations as to how much context can be gleaned from historical material, particularly in trying to track changes over very long periods of time. Evidence is patchy and there are inevitably large gaps. Comparison provides further "triangulation" to the material, thus building a more robust analytic process.

The trajectories of human societies and their representational images are both temporally and spatially dynamic. Populations have shifted across geographic territories in steady trickles and sometimes in great waves of migration. Ideas and images have moved and changed with them, and sometimes without them, carried by travellers, traders, émigrés and missionaries into new contexts. Thus images of water now widely separated in location may share some common geographic and cultural origins. It is clear that ideas and images from the ancient world flowed in a number of different directions, and the way these developed in different temporal and spatial environments is telling. How, for example, did Mesopotamian ideas about creative water beings (Nommos) become the Mami Wata cult across Africa? What happened as these ideas crossed Asia? Why is there apparently such strong continuity in Aboriginal Australian images of the Rainbow Serpent? And what happened to ideas about Maori taniwhas as they sailed across the Pacific? To some extent, human-environmental relationships 
and the cosmological ideas that support them may be seen as the outcome of a process in which people, scattering around the globe from their original clusters, took with them understandings of the world that, like "Chinese whispers", became transformed as they travelled through different times and places. Yet, even with multiple adaptations, they may retain vestigial links with common sources. Charting the movements of populations and ideas is therefore an important element of my project.

There are other potential commonalities. Anthropologists have written extensively about how humans use the material objects and processes of the world "to think with". Thus Levi-Strauss observed that animals are "good to think" because they provide metaphorical imagery for a host of characteristics and behaviours applicable to humans (1966). Rival and others have described how different societies "think with" trees to imagine concepts such as growth and kinship (1998). Lakoff and Johnston have considered how the material world provides the basis for a plethora of metaphors (1980), and Bourdieu has pointed to human cognitive tendencies to form "scheme transfers" that transpose one conceptual frame to another (1977). In my own work, I have considered how the particular characteristics of water and hydrological processes are used ubiquitously to imagine concepts of flow, movement, connection and creativity, observing that this cognitive employment of water's material qualities has persisted over time as well as space (Strang, 2004b, 2005). In examining water imagery and water beings, therefore, it is useful to extend this thinking to consider how these embody both the material characteristics of water and hydrology, and the imaginative concepts that these facilitate.

This 'material logic' is evident in the characteristics of the beings seen to personify water. Many take the form of serpents which, as well as tending to disappear underground or into water bodies like streams of water, share the serpentine movements and shimmering colours of such streams, and their capacity for transformation into different forms. Some, like dragons and Rainbow Serpents, are also expressive of the abilities of water to rise into and descend from the skies; some, like leviathans and sea monsters, are more located in and expressive of the powerful undercurrents of rivers and seas. Like other supernatural creatures, water beings are often composites, and many contain the characteristics of local aquatic fauna: eels, crocodiles, and so forth. For example, Tacon et al (1996) suggest that the earliest Rainbow Serpent images in Australia are based on a ribboned pipefish Haliichthys Taeniophora found on the northern coastline of the continent. 


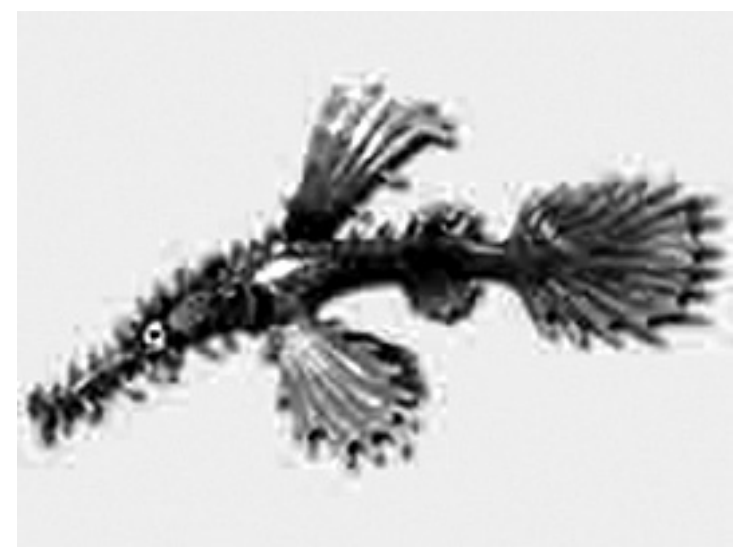

Fig. 1: Pipefish, from Tacon et al 1996

The commonalities that recur in the form of water beings and the ideas they express can therefore be supposed to have a dual basis: in the spatio-temporal transmission of ideas and practices, and in the common material characteristics of water, water-like creatures, and local aquatic fauna, and the use of these as an imaginative resource.

The widespread historical presence of water beings and the consistency of their forms provides a wide range of potential lines of inquiry, to the extent that one could begin almost anywhere. A logical way forward is to consider a geographically and cultural diverse "sample" of locations, seeking out those which have the fullest historical records available. Preliminary research suggests that usefully comparative historical and pre-historical representational "threads" can be picked up in India, Latin-America, Africa, Canada, Japan, the UK, Scandinavia, Australia and New Zealand, There is no space here to embark upon a wide range of examples, but taking these last two cases, it is possible to draw out a couple of usefully illustrative strands.

\section{Tracking the Rainbow Serpent}

Aboriginal people comprise about 2.5 percent of the Australian population. They are believed to have "beachcombed" and possibly boated their way to Australia along the coast of the Indian subcontinent and Indonesia, first crossing the (then much narrower) ${ }^{3}$ Torres Straits from Timor around 65,000 years ago, possibly in several waves of migration (Oppenheimer, 2003). Some of their earliest surviving images, for example the Gwion Gwion (Bradshaw) rock art paintings in the northern Kimberleys, are dated as being at least 17,000 years old, and depict people in boats, as well as offering pictures of deer, which have never been part of Australia's fauna. 
Like the groups that remained in Africa at that time, and the societies that settled en route, Aboriginal Australians were hunter-gatherers, making use of diverse local resources and living in small and widely scattered groups that moved systematically around their clan estates in seasonal patterns. Their environmental management was subtle, relying primarily on regular burning (to clear away snake-infested scrub and encourage "green pick" for game) and minor and rapidly biodegradable technologies such as small fish traps and weirs. The effects of "firestick management" have been much debated, but over many millennia it doubtless led to some alteration in the Australian landscape, favouring some plant and animal species over others, and possibly (along with hunting) leading the demise of some of these. But in migrating to an ecologically very fragile continent, it seems that Aboriginal population control and careful resource use enabled long-term sustainability, as well as a luxury of time in which to develop a highly sophisticated system of religious beliefs and practices which played a central role in managing this fine-tuned interaction between people and resources.

Through paintings of rituals and a range of natural and supernatural beings, early Aboriginal art works suggest that their cosmology constituted a classic "nature religion”. The earliest recorded rock art depicting Rainbow Serpents has been dated at approximately 6000 years ago (Chaloupka, 1993). As noted above, Tacon et al (1996) argue that this is modelled upon a local pipefish species. A plethora of such images then appeared across Australia, often incorporating elements of local fauna, but remaining fundamentally serpent-like.

The majority of the renditions of this figure are very serpentine in their form, expressing the formal qualities described previously and echoing the movements and characteristics of water. The recurrence of Rainbow Serpent beings in various forms in many parts of Australia, articulates core creative processes within Aboriginal cosmology:

The belief in the Rainbow Snake, a personification of fertility, increase (richness in propagation of plants and animals) and rain, is common throughout Australia. It is a creator of human beings, having life-giving powers that send conception spirits to all the waterholes. It is responsible for regenerating rains, and also for storms and floods when it acts as an agent of punishment against those who transgress the law or upset it in any way. It swallows people in great floods and regurgitates their bones, which turn into stone, thus documenting such events. Rainbow snakes can also enter a man and endow him with magical powers, or leave 'little rainbows', their progeny, within his body which will make him ail and die. As the regenerative and reproductive power in nature and human beings, it is the main character in the region's major rituals (Chaloupka, 1993:47). 


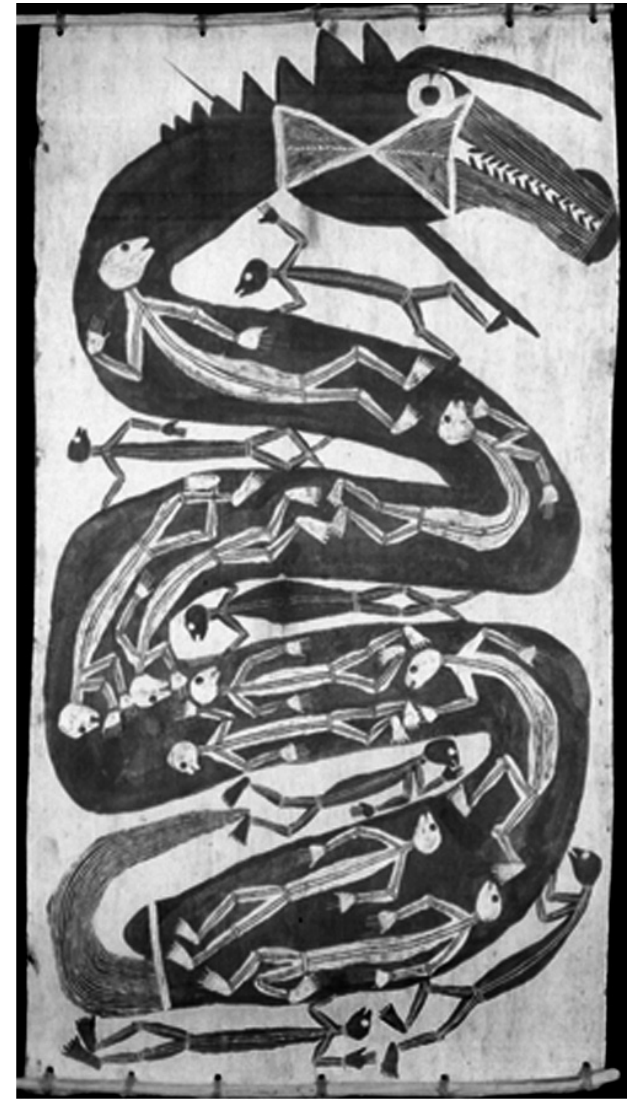

Fig. 2: Arnhem Land bark painting, showing Rainbow Serpent with ancestral beings inside. Pitt Rivers Museum Oxford

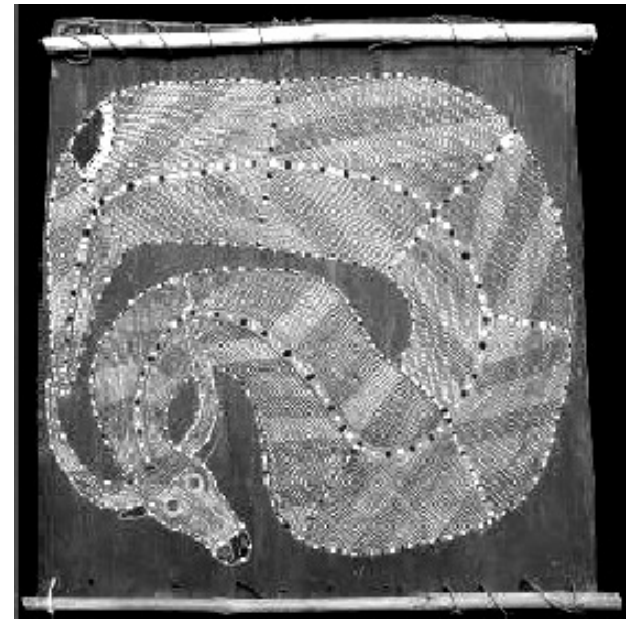

Fig. 3: Rainbow Serpent bark painting by Jimmy Njiminjuma in Tacon et al 1996

As this quote implies, there are multiple "Rainbow Story Places" all over Australia, containing serpents of various kinds. These can be female or male, and are often apparently androgynous. Not only does their dual gender underline their role as equal life creators, it also contrasts with more dualistic visions in which "nature" is envisaged as female.

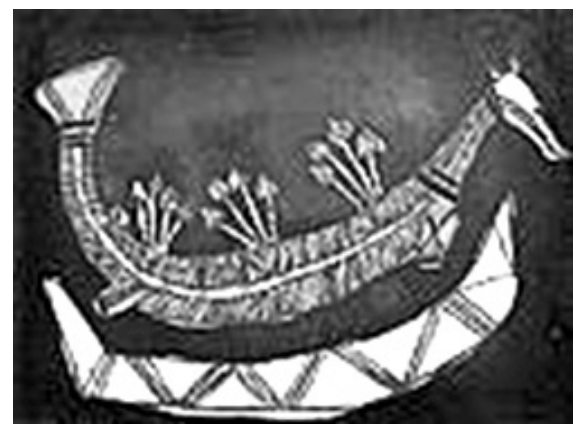

Fig. 4: Arnhem Land painting of the daughter of the original female Rainbow Serpent, Yingarna. Artist Bardyal Nadjamerrek. Aboriginal Art Online 
The Rainbow Serpent (or Rainbow as it is sometimes called) is not merely expressive of water, it may be said to be composed of water, representing aquatic flows through the environment (Strang, 2002, 2009a. See also Barber, 2005; Morphy and Morphy, 2006). Thus in Cape York, indigenous elders explain that the visible semi-circle of the rainbow, which arches over the land, is linked with its invisible "other" half, which inhabits the underground domain of the ancestral forces. Like water - as water - these forces creatively generate everything that is materialised and "becomes visible" in life and which, at death, returns to this immanent pool to be hydrologically recycled.In the Dreamtime, the Serpent generated the totemic species, usually animals and birds, ${ }^{4}$ who became the ancestors of subsequent human clans. It carved out rivers, pushed up hills, and created whole species of plants and animals before pouring back into the ground, where it remained, emanating power that even now has to be approached with care. Thus the most dangerous sacred sites (or poison places as they are called in northern Queensland) are those of Rainbow Serpent beings.

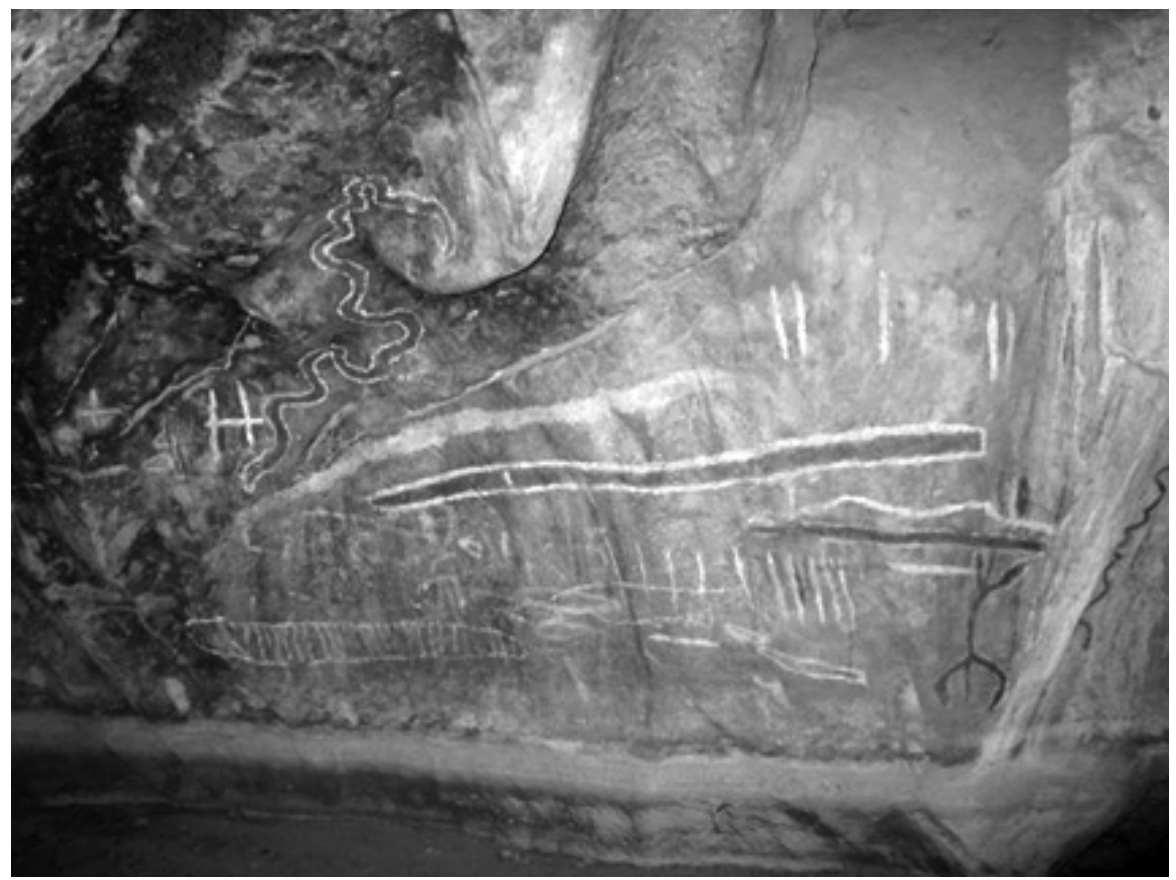

Fig. 5: Rock art serpents in Mungana Caves, north Queensland

In an oral culture these are contemporary or recent explanations of course, but the rock art and other archaeological evidence indicates considerable longterm stability in ideas and practices. That is not to say that Aboriginal ideas and lifeways have remained unchanged since the first migrants made their way across 
the Straits: merely that these seem to have been intensely conservative. This is borne out by descriptions of cosmological principles in which human beings, emerging spiritually from ancestral water sources, are exhorted to relive the lives of their totemic ancestors, learning their lexicon of bush lore, practising their rituals, and making use of local resources according to the blueprint provided by the ancestral stories, songs and images through which these ideas are transmitted intergenerationally. Within this mode of engagement, the ancestral beings, and the Rainbow Serpent in particular, define who belongs where, who has what rights, who can access resources, when and how. The Rainbow Serpent acts as a protective being, enforcing the Law if necessary. Thus there are multiple parables about how those who transgress (for example by entering places or taking resources without permission) will be swallowed by an angry Rainbow Serpent.

Thus one of the key things to be generated by the Serpent is knowledge and power. For example, ethnographies of Cape York describe a traditional ritual that entails being swallowed by the Rainbow Serpent. Unsurprisingly this centres upon immersion in water. In the swallowing and regurgitation process the initiate is given secret, sacred knowledge that opens the door to becoming a shaman or "clever doctor" (Taylor, 1984). Along with this ritual, traditionally undertaken only by a few people, all members of a community undergo various stages of initiation into the deeper sacred knowledge that lies at the heart of the Law. Provided at various stages of life, this gives elders the highly egalitarian gerontocratic power that constitutes Aboriginal forms of governance. It is the collective responsibility of the elders to ensure that such knowledge is passed on. In this sense, the regenerative powers of the Rainbow Serpent, and the circularity of the hydrological cycle, provide a perfect metaphor for the way that cosmologies and cultural heritage are perpetuated over time (Strang, 2011).

This reliable intergenerational process was obviously much disrupted by the arrival of European settlers in the late 1700s. There was an intensely traumatic period of violence in which indigenous populations were both decimated and dispossessed of their land, then dragooned into providing unpaid labour for colonial economic endeavours. There was no Treaty acknowledging their rights, as occurred in New Zealand; nor did they live in large and powerful tribal groups, being scattered widely and vulnerably in small clans. Missionaries went to considerable lengths to separate young people from the elders responsible for holding and transmitting traditional knowledge, and forbade the enactment of indigenous rituals. 
With the settlers came a combination of Christian ideas of dominion and stewardship over "nature", and a secular, pragmatically managerial view of the material environment. The long struggle for Aboriginal rights in Australia, which began with resistance to the colonial invasion, was followed by a long period of subjugation. Indigenous communities, pushed into enforced labour or missionisation, often led "double lives" in which traditional beliefs and practices were quietly maintained. Rather than replacing local belief systems, Christianity was overlaid like a larger umbrella over these. Traditional beliefs were already "underground" in a way, and could quite readily be rendered invisible to colonial eyes, at least until the ancestral landscape was more directly threatened.

But early European settlement in many areas was also driven by a desire for gold, and this aggressive invasion, not just of the land, but into the ancestral domain itself, was agonising to the indigenous population. For much of the colonial period their protests went unheard, but following the civil rights movement in Australia in the 1960s, which gave voice to indigenous concerns, there were many anguished protests about rapidly increasing mining activities and the dangers of penetrating the domain of the Rainbow Serpent. Indigenous protesters argued that such intrusion could kill generative ancestral beings (Kolig, 1987; Merlan, 1998; Strang, 2004a); it could threaten the health of their related human clans; and it could undermine the capacity of the land to provide resources for people and other species. It might even rile the Rainbow Serpent to the extent that it would emerge apocalyptically: "If the rocks of the mountain are disturbed the giant snake will emerge and destroy everyone in the world" (Lea and Zehner, The Australian Financial Review, 16 July, 1973). In indigenous terms, as this apocalyptic vision demonstrates, because the Rainbow Serpent "holds" and embodies the Law that constitutes Aboriginal society, the idea of its destruction is indeed "the end of the world". The Serpent and the hydrological cycles it represents are essential to the proper flow of events. Thus, in more recent years, proposals to dam waterways have elicited similar concerns, with activists protesting that such impediments to the movement of water will have dire effects (Strang, 2009b).

In the context of these protests, visual, textual and performative images of the Rainbow Serpent acquired multiple uses. They retained their traditional purpose in encapsulating the key elements of Aboriginal cosmology, describing a human-environmental relationship in which a material environment, imbued with sentient ancestral forces, worked in partnership with the human groups whose spiritual and social identity arose from and remained connected to the water circulating in and out of the land. But rising concerns about mining, as 
well as the land rights movement which gathered force in the 1970s, necessitated the outward explanation of Aboriginal culture. Images of the Rainbow Serpent therefore became integral to an educational process via which indigenous people hoped to communicate an understanding of their world to the wider Australian society. This, they believed, would engender greater respect for their beliefs and values and assist their claims for the restitution of lost lands.

This communicative effort has had some real effect, enabling sufficient understanding of how ancestral beings constitute relations between people and places to provide the basis for the Native Title Act in 1993. This - after 200 years of denial - acknowledged that indigenous Australians had indeed had a system of land ownership prior to European settlement, and (building on earlier legal efforts $)^{5}$ attempted to enshrine key indigenous principles in contemporary legal forms. This opened the door to a land claim process which, though it created an intense conservative backlash, has gone some way towards the restoration of rights to indigenous communities. Thus the Rainbow Serpent is not only used to speak for indigenous interests, it continues, in a contemporary setting, to play a key role in the creative regeneration of their lifeways.

Indigenous people in Australia now have what Altman calls a "hybrid" economy (2006), based on the maintenance of some traditional economic practices along with income from welfare and other forms of employment. But many communities, and particularly those who have retained or regained their traditional "country", 6 continue to promote beliefs and values that express key elements of a longstanding egalitarian human-environmental partnership. That is not to say they haven't learned (as they put it) to "talk the talk" of mainstream, much more human-centred approaches to environmental management: they have done so very effectively. For example, in the Mitchell River area of Cape York in the early 1990s, the indigenous community of Kowanyama initiated one of the first river catchment management groups in Australia. The same community has astutely reformed the traditional role of young "warriors" in protecting clan land to create "Aboriginal Rangers", making use of the language and authority of park rangers in a way that succeeded in protecting a whole range of indigenous interests (Strang, 1998, 2001). Rather than merely controlling tourist activities, these Rangers protect local resources, tracking down illegal fishers and ensuring that sacred sites are protected. They look after small groups relocating to "homelands", as well as the broader interests of the community. They also provide a useful interface with other land and water managers in the area, and are central to the community's efforts to regain ownership or at least some control of land and water appropriated in the colonial era. 
While there have been some efforts to promote the idea of bi-cultural governance in Australia, the small Aboriginal population, for the most part, retains aims that sit outside rather than in partnership with those of state and national governments. In a variety of ways, indigenous people continue to resist the imposition of governance, creating, in their own communities, what Scott describes as areas of Zomia which in subtle ways try to evade state and federal control (2009). Their aspirations are to maintain their own trajectory of development, and to support lifeways that adhere to their own beliefs and values. In this context it could be said that the Rainbow Serpent continues to maintain a powerful presence, resisting mainstream flows and regenerating a subaltern cosmos.

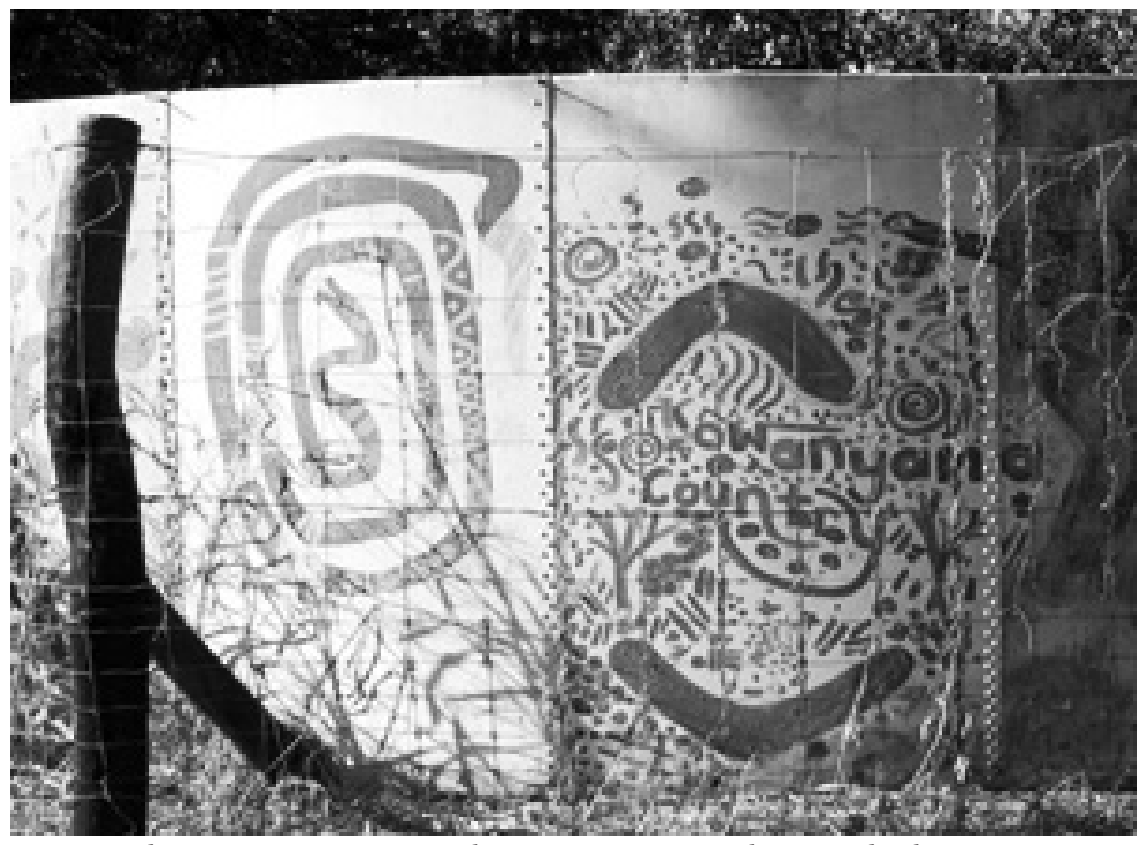

Fig. 6: Rainbow Serpent on water tank in Kowanyama, north Queensland

\section{Across the Tasman}

Maori people constitute about 16 percent of the New Zealand/Aotearoa population. Mitochondrial DNA evidence indicates that their ancestors came from south-east Asia, via Taiwan, island southeast Asia and the southwest Pacific (Chambers, 2008; Whyte et al. 2005). Evidence provided by Lapita pottery locates them in the Bismarck Archipelago, east of New Guinea, about 3,500 years ago, and it appears this population expanded eastwards from there, with their East Polynesian descendents possibly travelling as far as South America. They left a trail of Lapita materials through Melanesia, New Caledonia and into Fiji, Tonga and Samoa where, in the first millennium BC, they established 
what is now recognised as Polynesian culture (Sheppard et al. 2009). There is further contention as to exactly when and how this population came to New Zealand: longstanding stories of a single "Great Fleet" arriving in about 1350 have been questioned by suggestions of several waves of migration from Tahiti and the Marquesa Islands about 1000 years ago and by recent evidence that various groups made their way from the Cook and Society Island region (Howe, 2006). ${ }^{7}$ The idea of a Great Fleet is central to Maori traditions though, describing the arrival of a number of canoes (wakas) from a mythical place of origin called Hawaiiki, whose particular crews provided the basis for subsequent tribal groups.

These groups settled first around the more temperate eastern coasts of New Zealand/Aotearoa, making a living through a mix of hunting and gathering and crop cultivation, the proportion of each depending on local conditions. The hunting resulted in the extinction of some of some species, most notably the various types of Moa, a massive, flightless bird whose meat, bones and feathers were much in demand. ${ }^{8}$ Some large areas of forest were burned too, to clear land for horticulture, and this had impacts on a number of species; but, overall, Maori economic activities remained fairly low key and thus sustainable.

However, cultivation was a meaningful part of the Maori economy, and distinguished the Polynesian migrants from the hunter-gatherers across the Tasman in several key ways. It both required and enabled a greater degree of settlement and larger clusters of people, which encouraged the development of a more hierarchical set of social arrangements. Compared to Aboriginal Australians' more subtle managerial activities, it involved somewhat more directive environmental engagement. As well as some land clearing and levelling, cultivation meant fences, ${ }^{9}$ agricultural tools, planting and harvesting. The Maori settlers had brought with them a variety of plants, including sweet potatoes, taro, gourds and yams, and (with what must have been careful planning) less readily portable plants, such as mulberry trees. Though there is no evidence that they brought rice, Best suggests that they retained linguistic terms for it (ari and vari) (1941: 355), presumably from earlier use of this crop in South-east Asia. Rice had been brought to that region in the late Neolithic period by Austronesian speaking peoples, and it is there that archaeologists have found the first evidence of rice cultivation (Christie, 2007). In fact, South-east Asia was the home of some of the world's earliest irrigation schemes. Swamps and wetlands were modified for taro production both there and in the New Guinea highlands at around 7000 BCE (Ibid.). The forebears of the Maori were thus part of one of the first human ventures into more directive forms of engagement with water. 
Having arrived in New Zealand with an orientation towards cultivation, Maori groups had some practices in common with the European settlers who followed only a few hundred years later. Though the latter were farmers rather than shifting cultivators, and their technologies were more diverse than those of the Maori, their production was initially small in scale and focused heavily on subsistence-level provision of food for a small community of settlers. Thus, at least at the beginning, their economic practices didn't differ massively from those of the indigenous population. Obviously this changed as cattle and sheep were imported from Europe in larger numbers and farming began to intensify. The rapid forest clearance caused by a hungry timber trade also presented radically different ways of using resources. But, at least at the outset, there was some common ground in the respective economic modes of both communities, which may have made it more feasible for their developmental trajectories to converge.

Unfortunately, common ground was also a problem: as European settlement expanded, competition for land grew fiercer, leading to violent conflicts over territory. But compared to events in Australia this colonial conflict was much more equal in force. Though European technologies allowed the later colonists to prevail and to subjugate the Maori people to some extent, they also had to negotiate and make agreements with them, based in part on the Treaty of Waitangi, signed in 1840 in an effort to bring the violent conflicts to an end. The meanings and translation of this treaty remain much contested but, whatever its limitations, it opened a potential path to bi-cultural governance between the Maori and the European settlers, and led events towards the potential co-ownership and management of resources. It has consequently been possible for Maori groups to participate in social, political and economic practices at a national level. Though rural communities still struggle economically and educationally, there is now a large Maori middle class which participates fully in these processes, taking the lead in multiple negotiations about land, water and resources. This engagement seems to have had a considerable effect on indigenous relationships with the material environment, and these effects are discernible in changing cosmological ideas, discourses and representations.

The traditional cosmology contextualising and directing Maori lifeways was reflective of the mixed economy brought by waka from the Pacific. It describes both non-human and human agency. Water is portrayed as a primal source of power and creativity, and origin myths describe a water god called Tangaroa forming the world out of an era of creative chaos (te kore). There were other major gods, both male and female, representing the various aspects of the environment. And there were also human - or rather superhuman - figures in 
this creative era: ancestors who journeyed, hunted, fished and so forth. For example, New Zealand itself was pulled up out of the water by Maui, a major creative figure.

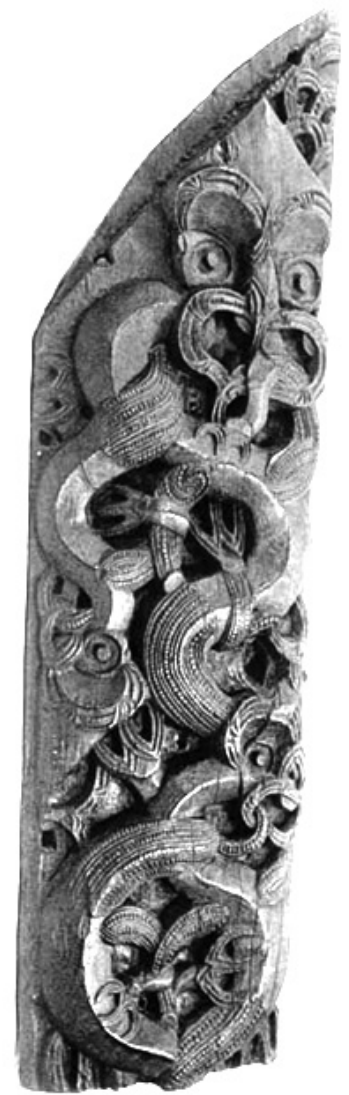

Fig. 7: House post (epa) in Taranaki, 1919. The figure at the top is a marakihau, or sea taniwha. Carving by Te Tuiti-Moeroa. Puke Ariki - Taranaki Museum \& Library

As well as comprising a key element in origin myths, water contained other supernatural beings, water serpents such as taniwha and marakihau (sea taniwha). In the creative era, it formed vital connections between people. Muru-Lanning describes, for example, how ancestral beings created the rivers of the Waikato region, establishing critical social and spiritual connections between the iwis (tribal communities) along their banks (2010).

The generative era also produced a world imbued with a sentient ancestral force, mauri, which, like the ancestral forces across the Tasman, remains immanent in all aspects of the material environment. Water's powerful mauri is indicated by a belief that the human spirit returns to water upon death: each must journey to the very tip of New Zealand, where the Pacific and Tasman seas 
meet, to slide down a pohutakawa tree root into an aquatic spiritual realm. The material environment is also regarded as being inhabited by a variety of spiritual beings, including the kaitiaki: guardian spirits whose role is to protect sacred places. The serpentine taniwha is one of these guardians, a water being whose powerful nature is indicated by the fact that this word can also be translated as "chief". Thus a tribal saying (pepeha) about the Waikato River, "He piko he taniwha, he piko he taniwha, Waikato taniwharau", is translated as "At every bend a taniwha or chief, at every bend a taniwha or chief, the Waikato River of one hundred taniwha (chiefs)" (Muru-Lanning 2010:116).

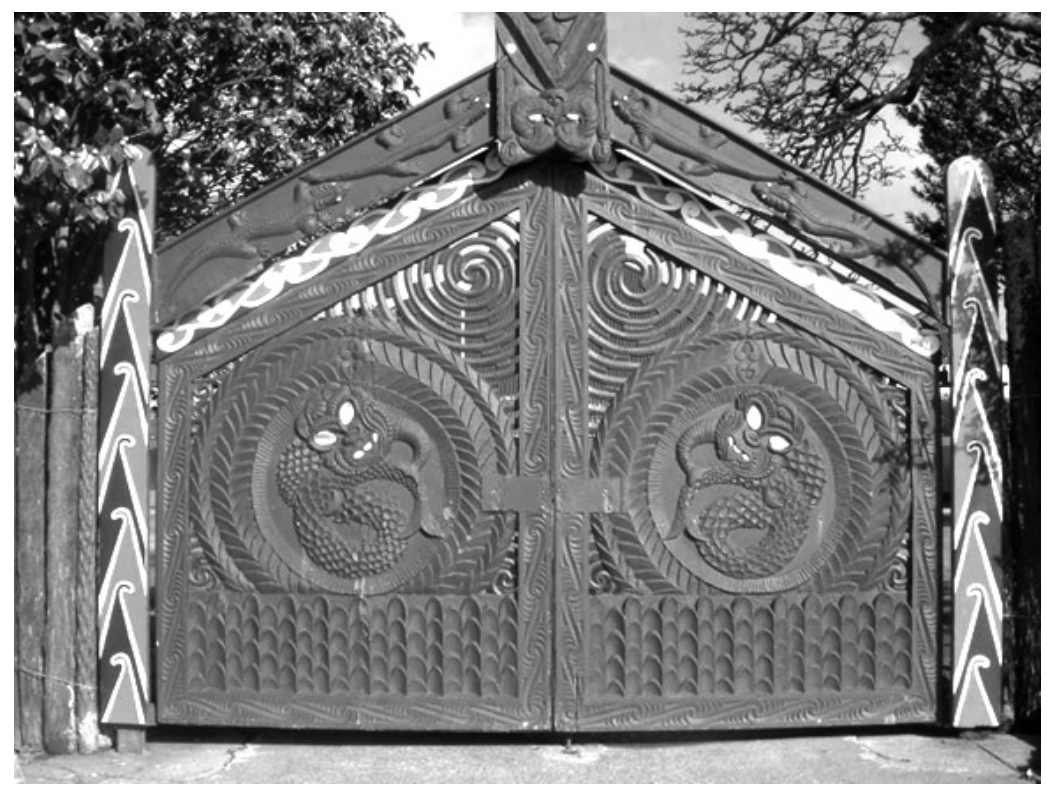

Fig. 8: Taniwhaon the Main Gates at TurangawaewaeMarae in Ngaruawahia. Photo: MaramaMuru-Lanning

Images of taniwha appear recurrently in Maori artworks, most particularly in the traditional carvings that decorate meeting houses (marae) and other key places. There is evidence of earlier usages, for example in the rock paintings in a cave shelter beside the Ōpihi River in South Canterbury.The form of the taniwha varies, but these are all variations on a theme: it remains a classic water being, sinuously combining elements of serpent and dragon, and sometimes other aquatic species. It may be plumed or feathered, but it is indubitably a water creature, with shimmering and sometimes multi-coloured scales, and a long, snake or eel-like tail which sometimes ends in a fishtail.

Its powers come into play when the sites of which it is a guardian are threatened. A taniwha called Tuhirangi was said to have accompanied a mythical 
explorer, Kupe, in his voyage to New Zealand, and to have been placed by him as a guardian in the Cook Strait. In the period since European colonisation, taniwhas have often been called upon to express resistance to the damming or diversion of waterways. Echoing indigenous protests across the Tasman, Maori activists have articulated concerns that such interference with water and its mauri runs contrary to the principles of order underpinning their traditional beliefs, impeding the proper movements of human and environmental processes.

In many ways, the notion of mauri, like descriptions of the Australian Rainbow Serpent's creative and retributive powers, provides a clear assertion of the agency located in water, as does the presence of taniwha who may be interpreted as a concentrated, personified manifestation of ancestral forces. To this extent, it is clear that like Australian Aboriginal belief systems, Maori cosmology locates considerable agency in non-human things, and promotes values of reciprocal care between people and their material surroundings. But there has also been some apparent divergence in the trajectories of each group, most particularly in recent years.

\section{Becoming Human}

The Australian Rainbow Serpent is depicted as a non-human creative figure which is only "ancestral" to the extent that it generates human spirit beings (usually spewing them into the world). It also generates all of the other totemic ancestral beings, the animals and birds, whose creative journeys across the landscape combine accounts of the physical and behavioural characteristics of those species with more human kinds of events and practices. These beings are often transformed from animal to human form, or vice versa. Such transformations can also occur in Maori mythology. For example, Orbell recounts a myth from the Waikato region which describes how an ancestral chief, Tuheitia, was drowned by a jealous brother-in-law and became a taniwha who has since reappeared to the local iwi to warn them of impending danger (1995:224).

However, the taniwha comes from a somewhat more humanised religious tradition, and unlike the rainbow serpent it is often depicted with a human face (usually decorated with traditional tattoos (moko). In the Waikato region, the language describing the river as a "river ancestor", Tupuna Awa, also implies human characteristics, locating this ancestry alongside customary genealogies, which describe in detail each family's long lines of connection back to the original waka of the Great Fleet. Thus not just rivers, but also mountains, and other features of the local environment, are placed within a single genealogical system. This incorporation is clear in evidence presented to the Environment 
Court in an earlier dispute over the Waikato river:

This genealogical relationship is one of the foundations upon which the Maori culture is based. It is known as "whanaungatanga". Whanaungatanga in its broadest context could be defined as the interrelationship of Maori with their ancestors, their whanau, hapu, and iwi as well as the natural resources within their tribunal boundaries e.g. mountains, rivers, stream, forests etc (Ngati Rangi and Ors decision, 2004:28, in Muru-Lanning, 2010:56).

The inclusion of aspects of the material world into this single genealogy is indicative of some sense of shared human-environmental agency, but it involves an incorporation of non-human things into a human system, rather than - as in Australian indigenous cosmological ideas - the incorporation of human groups into a totemic system defined by non-human figures. Though they sometimes take the form of animals and birds, key Maori ancestral beings are most often human or semi-human. And the way of life described in their ancestral stories places greater direction and power over the material world in human hands.

As well as being more inclined to give the balance of agency to humans, traditional Maori cosmology has been greatly influenced by Christianisation. Missionary efforts in the Pacific were either more forceful or persuasive than in Australia. Possibly Christianity simply meshed more readily with the Maori cosmos, with its greater emphasis on humanised religious figures and its relatively steep hierarchies which already contained notions of higher ranking gods and even a supreme being (Io). At any rate, Christian evangelism achieved a much more integrated, tighter hold on people's lives, being fully and enthusiastically adopted in many Pacific communities, including those who came to New Zealand.

As I have observed elsewhere (Strang, 1997), though there are vestiges of previous, more nature-oriented belief systems in the early parts of the Bible, Christianity places the agency in human-environmental relationships squarely in the hands of a humanised and male God, framing the material environment, including water, as subject to and an expression of His will. Thus God sends the rain to fertilise the earth and feed the world - or sends floods to punish unruly human societies when they transgress. In Biblical mythology, paganism, in the form of the serpent, is invariably slain by male culture heroes. The relevance of this assertion of human authority over water beings is well expressed by Maori interpretations of the figure of St George and the Dragon, an image which appeared on the gold sovereigns brought to New Zealand by British settlers: 
In Te Ao Hou in March 1959, Leo Fowler, born in 1902, described a story told to him about how the dragon slain by St George on the sovereign represented a taniwha: "Personally, I have never seen a taniwha, nor I expect have readers. I have met some who told me they had seen one, and they were people I had every reason to respect and to believe. My old friend Nepia Pomare, (a Ngapuhi and my Maori godfather) once told me that the taniwha on our gold sovereigns was not unlike a taniwha he had once seen. This taniwha, whose name he could not utter, (so tapu was it) had a body very like that of the taniwha on the sovereign, but the wings were only partly formed and the head was the head of a manaia [stylised carving of a supernatural being]" (Basil Keane. 'Taniwha', Te Ara - the Encyclopedia of New Zealand, updated 1-Mar-09URL: http:// www.TeAra.govt.nz/en/taniwha/7/3).

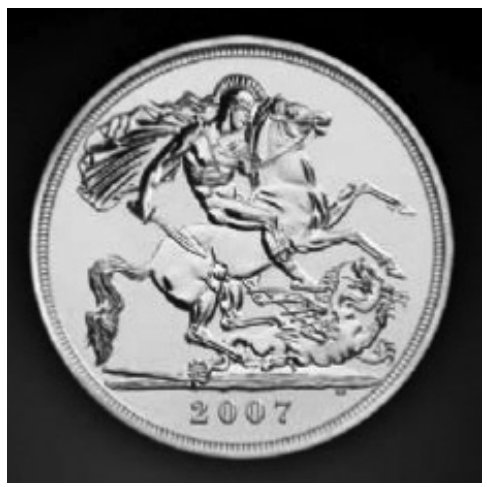

Fig. 9: The British gold sovereign. (Basil Keane. 'Taniwha', Te Ara - the Encyclopedia of New Zealand, updated 1-Mar-09 URL: http:/ /www.TeAra.govt.nz/en/taniwha/7/3)

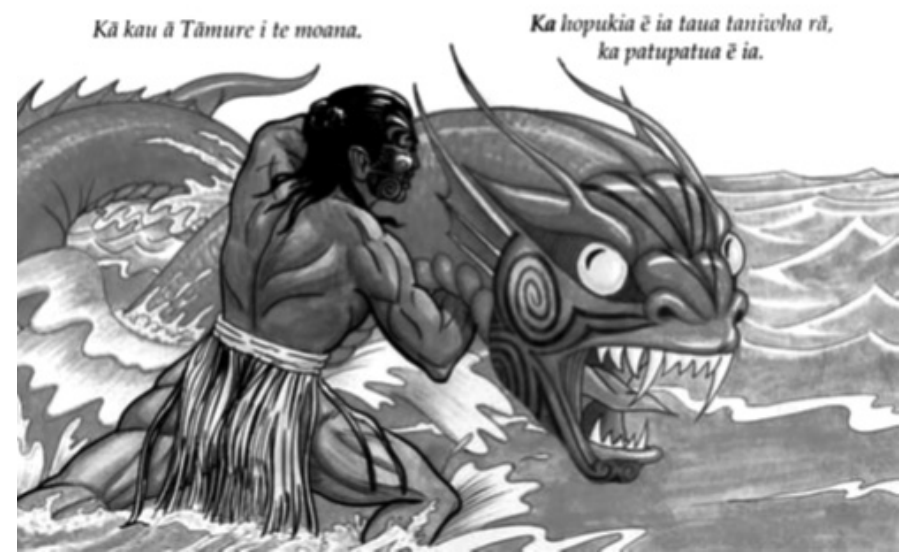

Fig. 10:Tāmure defeating the taniwha. Artwork by Manu Smith (in Bacon 1996:12) 
There is a Maori myth which echoes this subjugation of a powerful water being. It describes how a hero called Tāmure wrestled with a man-eating sea taniwha that lived in an underwater cave at Piha (a beach just west of Auckland, where rip tides regularly drown swimmers). He hit it with his greenstone weapon (mere pounamu) which had the power to overcome any taniwha, injuring it so that it no longer ate people (Bacon, 1996). Such epic battles are common in Maori myths, valorising human dominance over other species or the elements, and, like the St George legend, presenting an image of powerful masculine culture triumphing over "the other".

However, St George and Tāmure are the least of the threats to the survival of water serpent beings. Growing out of Judao-Christian moves to valorise rationality, science has overtaken St George and the other dragon slayers in killing off mythological water beings and establishing the dominance of male "culture" over (increasingly) female "nature". Though vestigial ideas about energies and consciousness persist, a rationalist perspective has also had a dampening effect on ideas about sentience and agency in land and waterscapes. Most contemporary water management deals with the material environment in secular Cartesian terms, adopting a techno-managerial mode of engagement which is more concerned with measurement than with meaning. The influence of this scientific worldview, along with the embracing of Christianity, have given rise to some changes in Maori relations with water, and this is reflected in some striking differences between the images of water beings produced in the first half of the $20^{\text {th }}$ century, and contemporary art works, which are more clearly humanised, suggesting a further shift in the location of agency.

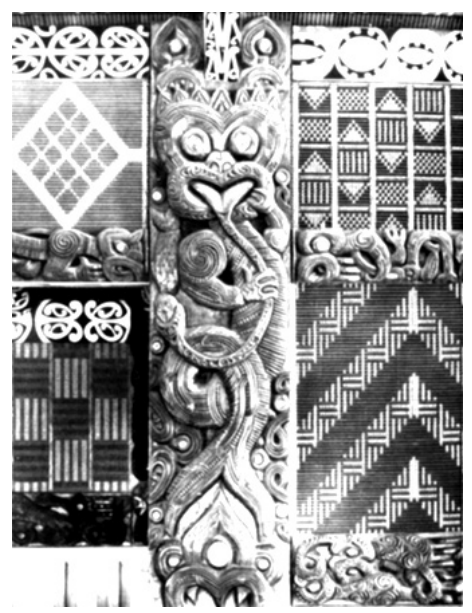

Fig. 11: Marakihau in the meeting-house called Poho-o-Rawiri at Gisborne. Carved by the late Tama te Kapua Raihi (Journal of the Polynesian Society, 1957:3) 


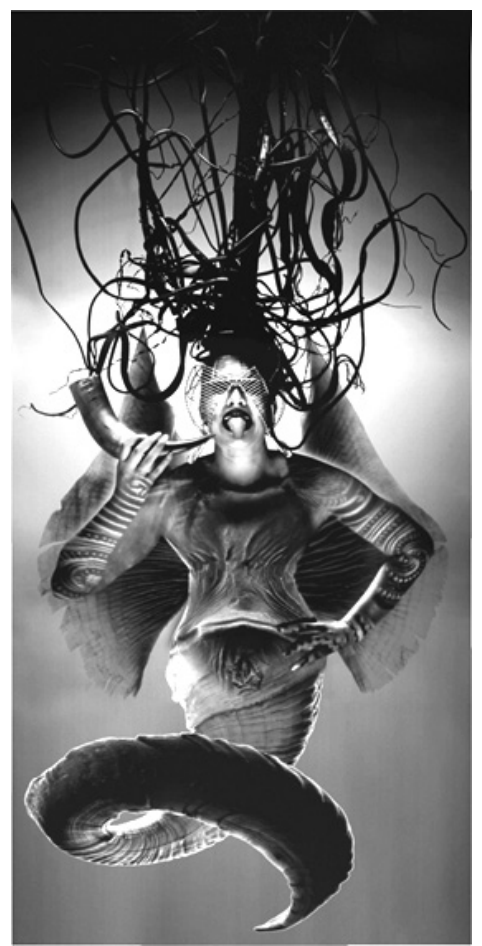

Fig. 12: Contemporary Marakihau by Lisa Reihana, Museum of New Zealand Te Papa Tongarewa

Though taniwha are still called upon regularly in New Zealand to attest to the subaltern belief system subsumed by Christianisation, unlike Rainbow Serpents, they do not propose a wholly "other" way of engaging with land and water, in which agency is shared equally between humans and non-humans. The image of the taniwha is employed, instead, to support the authority of human groups. In recent years this difference has become more pronounced. MuruLanning observes that powerful contemporary leaders can be represented (or represent themselves) as taniwha:

The symbolism of taniwha, chiefs, kaitiaki and guardians are also manipulated by core members of the Kingitanga to denote Waikato iwi and the Kingitanga's authority in relation to the river. Indeed, many people perceived Robert Mahuta as a great taniwha when he was alive as he was not only a well known chief but also a self-professed kaitiaki of the river (2010:116).

Writing about contemporary negotiations over the control and management of the Waikato River, she notes that there has been a key discursive shift in the terminology used to describe the ancestral role of the river: 
Tupuna Awa defined the Waikato River as an important tribal ancestor. In contrast, Waikato-Tainui's river negotiators and Crown officials subsequently embraced the idiom of Te Awa Tupuna, translated as "ancestral river", which redefines Waikato Maori understandings of the river. This discourse emphasises iwi identity, iwi partnerships with the Crown and a vision of co-managing the Waikato River (2010:ii).

This shift towards a more managerial mode of engagement is also illustrated by the replacement of the phrase "Guardians of the Waikato River", agreed as the descriptor for a joint management agreement between the Crown and Waikato-Tainui Maori in 2008, with "Waikato River Authority", which is quite literally more authoritative in its reframing of the relationship between people and water (Muru-Lanning, 2010:11).

It appears, therefore, that Maori groups are not just "talking the talk" in relation to introduced notions of environmental management, they are also "walking the walk", by integrating its precepts into their own activities. Their political efforts to regain ownership or control over land and water are aimed not at a separate Zomia in which their own subaltern traditions are revived and upheld, but towards the achievement of equal bi-cultural management of the country's resources. Building on the initial Treaty of Waitangi (1840), they have been successful in ensuring that this role has been legally recognised, for example in the Resource Management Act (1991) which includes various provisions for the consultation and inclusion of Maori in decision-making processes.

\section{Conclusion}

It appears that the worldviews of indigenous communities in both New Zealand and Australia have been considerably influenced by the introduction of European ideas and practices in the period since colonisation. These influences are apparent not only in their representations of water beings, but also in their use of these in legal and political arena to promote indigenous aims and interests. However, it is also clear that, although their cosmologies have some important common elements, there has been a much lengthier divergence in the trajectories of their particular human-environmental relationships. Aboriginal Australians have maintained an intensely conservative belief system, which has proved highly resistant to change, even in the most traumatic of colonial circumstances. The underlying precepts of this system, which comprise a true "nature religion" in giving significant agency to non-human species and things, continue to guide their lifeways. Thus, though willing to "talk the talk" sufficiently 
to co-manage resources and have a voice in the decision-making processes of a wider Australian society, they are unwilling to discard the close, affective and egalitarian relationships with places that provide core meanings in their lives.

Maori groups in New Zealand arrived on its shores with a religious cosmology that, although it gave considerable agency to non-human species and things, was more hierarchical in its form, had already incorporated more directive modes of environmental engagement, and was more inclined to place the balance of power in human and particularly in male hands. This worldview resonated more readily with the ideas introduced by Christian missionaries and colonists, providing sufficient common ground to form the basis of a potential co-managerial approach. It may therefore be seen that, rather than seeking to diverge radically, the trajectory of Maori human-environmental relations has run in a direction that, if not quite parallel, has shifted increasingly to run in accord with that of the European settler society in New Zealand, albeit with some intention of pulling the latter towards its own aims.

As these case studies illustrate, a comparative examination of changing ideas and representations of water over time in two indigenous communities provides some insights into the parallels and divergences in the trajectories of their respective human-environmental relationships. It illuminates the ways that they balance power and agency in these interactions, with concomitant effects on the human and non-human participants.

Recebido em 08/06/2011

Aprovado em 15/06/2011

Veronica Strang is an environmental anthropologist and Executive Director of the Institute of Advanced Study at Durham University. Her research focuses on human-environmental relations, and in particular on people's relationships with water. She is the author of The Meaning of Water (Berg, 2004); Gardening the World: agency, identity and the ownership of water (Berghahn, 2009) and (co-edited with Mark Busse) Ownership and Appropriation (Berg, 2010). Named as one of UNESCO's Lumieres D'Eau in 2007, she has published extensively on water issues in the UK and in Australia. 


\section{Notes}

1. Though popular contemporary mythology has downplayed this aspect of dragons, they have always been associated with water historically. Some inhabit water itself, others are associated with underground caves, wetlands and swamps.

2. I refer here to Durkheim's well known assertion that societies make their religions in their own image (1966).

3. Changes in temperature and thus sea levels form a key part of the picture of population movements, providing a set of pressures and opportunities for migration.

4. Totemic ancestors could also be plants and other aspects of the environment.

5. For example the seminal Land Rights (NT) Act of 1976.

6. "Country" is a term used to describe clan estates, ie land traditionally owned by a specific group.

7. Earlier theories have been challenged by a range of evidence: radio-carbon dating of archaeological sites; DNA analysis of people and also of the Pacific Rat; and analyses of volcanic ash.

8. Some of these birds reached a height of 3.7 metres and weighed about $200 \mathrm{~kg}$.

9. Initially - before pigs were introduced by Europeans - these were simple reed fences to keep out swamp hens (pukekos) (Best, 1941:358). 


\section{References}

Aboriginal Art Online. Accessed 29.5.11. D: \Documents and Settings $\backslash$ loanpool $\backslash$ My Documents $\backslash$ Research $\backslash$ Dragons $\backslash$ Dragons pics (all) $\backslash$ Rainbow Serpent and the Dreamtime - Aboriginal Art Online.mht

ALTMAN, J. 2006. "Nomads Triumphing Today: how some hunters in Arnhem Land engage with the State, the market and globalisation”. Seminar paper. University of Auckland, May 3rd 2006.

APPADURAI, A. 1986. The Social Life of Things: commodities in cultural perspective. Cambridge: Cambridge University Press.

BACON, R. 1996. A Tamure Me Te Taniwha. Auckland: Waiatarua.

BARBER, K. 2012. "Interpreting Texts and Performances”. In: R. Fardon et al. (eds). A Handbook of Social Anthropology. London: Sage.

BARBER, M. 2005. "Where the Clouds Stand: Australian Aboriginal Relationships to Water, Place and the Marine Environment in Blue Mud Bay, Northern Territory”. PhD Thesis, Australian National University.

Best, E. 1941. The Maori. Volume II. Wellington: The Polynesian Society.

BOOMGAARD, P. (ed.). 2007. A World of Water: rain, rivers and seas in Southeast Asian histories. Leiden: KITLV Press.

BOURDIEU, P. 1977. Outline of a Theory of Practice. Transl. R. Nice. Cambridge: Cambridge University Press.

CHALOUPKA, G. 1993. Journey in Time: the 50,000-year story of the Australian Aboriginal rock art of Arnhem Land. Chatswood, N.S.W.: Reed.

CHAmBERS, G. 2008. "Genetics and the Origins of the Polynesians". In: Encylopedia of Life Sciences. Chichester UK: John Wiley.

CHRISTIE, J. 2007. "Water and Rice in Early Java and Bali”. In: Peter Boomgaard (ed.). A World of Water: rain, rivers and seas in Southeast Asian histories, Leiden: KITLV Press. pp. 235-258.

DAVIS, W. 1986. The Serpent and the Rainbow. London: Collins

DESCOLA, P. and PALSSON, G. (eds). 1996. Nature and Society: anthropological perspectives. London: Routledge. 
DREWAL, H. 2008. Sacred Waters: arts for Mami Wata and other divinities in Africa and the diaspora. Bloomington: Indiana University Press.

DURKHEIM, E. 1966. The Elementary Forms of the Religious Life. New York: Collier Books. GAL, S. (in press). “The Role of Language in Ethnographic Method”. In: R. Fardon, O. et al. (eds.). A Handbook of Social Anthropology. London: Sage.

GIBLETT, R. 1996. Postmodern Wetlands: culture, history, ecology. Edinburgh: Edinburgh University Press.

HARRIS, R. 2003. "Making a Place for Taniwha in Culture and Law". Resource Management Journal, 11(1):18-22.

HARRISON, P. 1999. "Subduing the Earth: Genesis 1, early modern science, and the exploitation of nature”. The Journal of Religion, 79(1):86-109.

HOWE, K. 2006. Vaka Moana. Voyages of the ancestors: the discovery and settlement of the Pacific. Auckland: Bateman.

INGOLD, T. 2000. The Perception of the Environment. London: Routledge.

JUUTI, P.; KATKO, T. and VUORINEN, H. 2007. Environmental History of Water: global views on community water supply and sanitation. London: IWA Publishing.

KOLIG, E. 1987. The Noonkanbah Story. Dunedin N.Z.: University of Otago Press.

LAKOFF, G. and JOHNSON, M. 1980. Metaphors We Live By. Chicago: University of Chicago Press.

LAYTON, R. and UCKO, P. (eds.). 1999. The Archaeology and Anthropology of Landscape: shaping your landscape. London: New York: Routledge.

LEA, J. and ZEHNER, R. 1986. Yellowcake and Crocodiles: town planning, Government and society in northern Australia. Sydney, Boston, London: Allen and Unwin.

LÉVI-STRAUSS, C. 1966. The Savage Mind. Chicago: University of Chicago Press.

MERLAN, F. 1998. Caging the Rainbow: places, politics and Aborigines in a north Australian town. Honolulu: University of Hawai'i Press.

MORPHY, H. 1991. Ancestral Connections: art and an Aboriginal system of knowledge. Chicago: Chicago University Press.

. 2010. "Not Just Pretty Pictures": relative autonomy and the articulations of Yolngu Art in its context". In: V. Strang and M. Busse (eds.). Ownership and Appropriation. Oxford, New York: Berg. pp. 261-286. 
MORPHY, H. and MORPHY, F. 2006. "Tasting the Waters: discriminating identities in the waters of Blue Mud Bay”. Journal of Material Culture, Vol 11(1/2):67-85.

MURU-LANNING, M. 2010. "Tupuna Awa and Te Awa Tupuna: competing discourses of the Waikato river”. PhD Thesis. University of Auckland.

OESTIGAARD, T. 2005. Water and World Religions: an introduction. Bergen: SFU and SMR.

OPPENHEIMER, S. 2003. Out of Africa's Eden: the peopling of the world. Johannesburg: Jonathan Ball.

ORBELL, M. 1995. Maori Myth and Legend. Christchurch: Canterbury University Press.

RIVAL, L. (ed.). 1998.The Social Life of Trees: anthropological perspectives on tree symbolism. Oxford, New York: Berg.

SCOTT, J. 2009. The Art of Not Being Governed: an anarchist history of upland Southeast Asi. New Haven: Yale University Press.

SHEPPARD, P., THOMAS, T. and SUMMERHAYES, G. 2009. Lapita: Ancestors and Descendants. Auckland: New Zealand Archaeological Association.

STRANG, V. 1998. "The Strong Arm of the Law: Aboriginal Rangers and Anthropology". Australian Archaeology, December 1998, n 47:10-29.

. 2001. "Negotiating the River: cultural tributaries in Far North Queensland”. In: B. Bender \& M. Winer (eds.). Contested Landscapes: movement, exile and place. New York: Berg. pp. 69-86.

. 2002. "Life Down Under: water and identity in an Aboriginal cultural landscape". Goldsmiths College Anthropology Research Papers, n. 7. London: Goldsmiths College.

2004a. [2001] "Poisoning the Rainbow: cosmology and pollution in Cape York”. In: A. Rumsey \& J. Winer (eds). Mining and Indigenous Lifeworlds in Australia and Papua New Guinea. Wantage: Sean Kingston Publishing. pp. 208-225.

2004b. The Meaning of Water. Oxford, New York: Berg.

. 2005. "Common Senses: water, sensory experience and the generation of meaning". Journal of Material Culture, 10 (1):93-121.

. 2009a. "Water and Indigenous Religion: Aboriginal Australia". In: T. Tvedt and T. Oestigaard (eds.). The Idea of Water. London: I. B Tauris. pp. 343-377. 
2009b. Gardening the World: agency, identity and the ownership of water. Oxford, New York: Berghahn.

. 2010. "The Summoning of Dragons: ancestral serpents and indigenous water rights in Australia and New Zealand". Anthropology News, Special Issue, The Meaning of Water: 5-7. http://blog.aaanet.org/2010/02/03/ the-meaning-of-water-february-an-now-online/

2011. "Living Water, Living Culture: the Rainbow Serpent and Aboriginal heritage in Cape York". Public Lecture for International Day for Monuments and Sites, hosted by Cairns Institute, the Ministry of Environment and Resources and the International Council on Monuments and Sites, James Cook University, Cairns, April 18 2011.

TACON, P., WILSON, M. and CHIPPINDALE, C. 1996. "Birth of the Rainbow Serpent in Arnhem land rock art and oral history”. Archaeology in Oceania, 31:103-124.

TAYLOR, J. 1984. Of Acts and Axes: an ethnography of socio-cultural change in an Aboriginal community, Cape York Peninsula. PhD thesis, James Cook University.

TVEDT, T. and JACOBSON, E. 2006. A History of Water. London: I.B. Tauris.

WHYTE, A., MARShAll, S. and CHAMBERS, G. 2005. "Human Evolution in Polynesia”. Human Biology, 77:157-177. 


\section{Resumo}

Este artigo baseia-se em pesquisa sobre representações visuais de seres aquáticos e sua capacidade de articular relacionamentos humano-ambientais. Seres aquáticos (como serpentes arco-íris e taniwhas) são relevantes em muitas cosmologias culturais diferentes, mais particularmente aquelas que se orientam no sentido de "religiões da natureza", nas quais as paisagens terrestres e aquáticas são vistas como animadas por seres sensíveis. As análises destas imagens visuais, e suas transformações ao longo do tempo, sugerem que, como reflexo de crenças cosmológicas e valores, elas podem iluminar o passado e fornecer insights úteis para mudanças fundamentais nas relações humanas com a água. Como representações das visões de mundo de grupos particulares, elas também têm uma função vital nos debates contemporâneos sobre gestão ambiental, propriedade e controle dos recursos hídricos. Baseando-se em exemplos da Austrália e Nova Zelândia, este artigo considera, portanto, o papel das imagens como indicadores temporais de mudança e como representações simbólicas de cosmologias subalternas em sociedades pós-coloniais. Examina também as implicações potenciais da pesquisa para a teoria e o método em antropologia visual. Ao manter uma abordagem etnograficamente situada objetiva, demonstra que as transformações nas relações humanas com a água, expressas através de imagens visuais de seres aquáticos, continuam a dirigir os conflitos contemporâneos sobre a propriedade da água, sua gestão e utilização.

Palavras-chave: seres aquáticos, cosmologia, relações humano-ambientais, representações da água

\section{Abstract}

This paper describes research concerned with visual representations of water beings and their capacity to articulate human-environmental relationships. Water beings (such as rainbow serpents and taniwhas) play a role in many different cultural cosmologies, most particularly those oriented towards 'nature religions' in which land and water scapes are seen as being animated by sentient beings. Analyses of these visual images, and their transformations over time, suggest that as reflection of cosmological beliefs and values, they can illuminate the past and provide useful insights into key changes in human relationships with water. As representations of the worldviews of particular groups, they also have a vital function in contemporary debates about environmental management and the ownership and control of water resources. Drawing on examples in Australia and New Zealand, this paper therefore considers the role of such images as temporal indicators of change, and as symbolic representations of subaltern cosmologies in post-colonial societies. It also examines the potential implications of the research for theory and method in visual anthropology. By retaining an ethnographically situated approach it aims to demonstrate that transformations in human relations with water, as expressed through visual imagery of water beings, continue to direct contemporary conflicts over water ownership, management and use.

\section{Keywords:}

water beings, cosmology, human-environmental relations, representations of water 